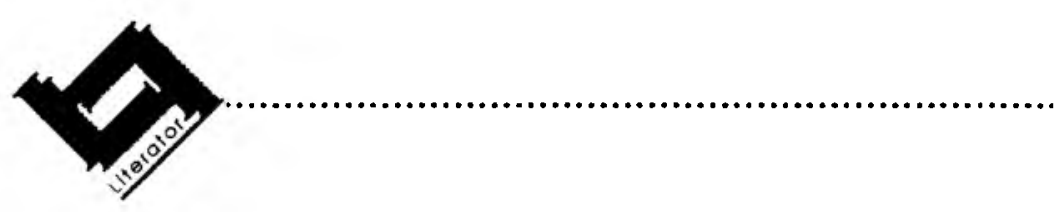

\title{
Between nostalgia and parody: The representation of childhood and youth in Afrikaans literature of the nineties
}

\author{
H.P. van Coller \\ Department of Afrikaans and Dutch \\ University of the Free State \\ BLOEMFONTEIN \\ E-Mall: fgvc@rs.uovs.ac.za
}

\begin{abstract}
Between nostalgia and parody: The representation of childhood and youth in Afrikaans literature in the nineties
\end{abstract}

While Afrikaans literature of the sixties can be seen as typically modernist, work of the later part of the eighties and of the nineties clearly shows all the characteristics of postmodernism. Against this backdrop recent Afrikaans prose writing dealing with the representation of childhood and youth can be discussed on the basis of a few of the best and most representative texts. A tentative conclusion is that Afrikaans writing in the nineties focuses on the individualized past, an approach Linda Hutcheon calls "historical metafiction". The authorial stance in these texts fluctuates between what can be termed nostalgia and parody, and should be seen as part of a traumatic psychological process facing white South Africans in particular, namely having to deal with the past.

In Afrikaans prose writing the nostalgic stance is especially prevalent in the (traditional) prose writings of authors on the right of the political spectrum. In contrast the parodic stance (dominant in recent Afrikaans prose writings) not only leans toward postmodernism - the prevailing paradigm in the Afrikaans literary context - but can almost without exception be termed "leftist" and "progressive".

\section{Periodization}

Distinguishing periods or traits in literary history is an attempt to create order through a process of abstraction, because one can never posit that a literary text is 
an unique phenomenon. Many methodological problems adhere to the process of periodization and it is therefore prudent to heed Wellek and Warren's (1976:262) waming against a metaphysical or an extreme nominalistic view. Nevertheless it remains a practical convenience to see a period as "a time section dominated by a system of literary norms, standards and conventions" (Wellek \& Warren, 1976: 265) and with an underlying code (Lotman, 1973) with syntactic, semantic and pragmatic components (Fokkema \& Ibsch, 1987).

One should not lose from view the provisional nature of any working hypothesis (which is encapsulated in each system or period definition). This omission could have far-reaching effects, especially in the case of the interpretation of concrete texts that can be forced into the systemic mould of the interpreter. It is prudent to take heed of Crane's warning (1975:296) that it is dangerous to regard a period as a definite system of happenings - something like the plot of a novel in which a great many diverse characters and episodes are unified, more or less completely, by a principal action or theme.

In their important work on Modernism, Fokkema and Ibsch (1987) concentrated not primarily on texts, but rather on readings thereof. This favouring of the esthetical object rather than the artefact is motivated by the fact that "literariness" is determined by readers embedded in a specific time frame, rather than on objective qualities inherent in the text; it is their horizon of expectation which is at stake and their penetration of it that causes an esthetic effect. This approach is firmly rooted in Prague Structuralistic and Russian Formalistic thinking: Mukarovsky and the esthetic function, Sklovskij and ostraneni, and Tynjanov's explanation of the perpetuum mobile of the literary polysystem.

Possible explanations for change in a literary system only partially pertain to actual historical events. Internal change can be related to Thomas Kuhn's definition of a scientific paradigm: if coherence disappears within a specific paradigm it is due to the fact that this paradigm no longer can provide answers to specific problems (cf. Fokkema \& Ibsch, 1987:14). In a specific literary "paradigm" or structured time section (code) at any given moment new questions of a metaphysical, epistemological or ontological nature may arise that cannot be solved within the framework of that given code.

The literary code is described by Fokkema and Ibsch (1987:30) in the words of Jurij Lotman as a secondary modelling system because the codes of literature "parasitize" on the linguistic code. "Real life experience" is brought into play by actual readers who read texts against their own reading and experiences and whose reception signifies in a sense a new literary code. Any new literary code, a period in the making, displays syntactic, semantic and pragmatic features. 
In recent studies (Van Coller, 1995a and 1995b) a proposal for the periodization of Afrikaans literature since 1955 has been put forward. Broadly speaking three codes can be discerned:

- The modernist code (1955 - 1973) that can be characterized by key words like alienation, observation, existentialism, the outsider, the exile and the expatriate. These semantic features gave rise to syntactical components that confirmed the provisional, hypothetical nature central to these literary texts: a predilection for subjective narrative techniques (e.g. the stream of consciousness) and homodiegetic narrators, the breaking of narrative continuity, structural experimentation, open-endedness, violation of natural syntax, etc.

- Literature of contestation:

- littérature engagée (1973 - 1978) with its focus on the political situation in South Africa, especially apartheid and its effects, often implicitly referring to recognizable people as literary case histories.

- Frontier literature (the eighties) being an authentic depiction of the Border War and its effects on all South Africans; often narrated from an I-perspective.

- The postmodernist code:(the nineties). This latter period is clearly distinguishable from earlier periods in Afrikaans literature.

Its syntactical component illustrates all the typical traits of postmodemism, namely genre-hybridism, text-fragmentation, metafictional digressions, intertextuality, etc. As far as its semantic component is concerned, relativism, debunking (especially of "master narratives"), scepticism, narcissism and carnivalization are key phrases that characterize the "mood" of postmodemism in Afrikaans literature. The intended perlocution of many of these texts - in contrast to the established tradition in Afrikaans literature (cf. Van Coller, 1993) - is the view that the essence of literature (and life) need not lie in serenity, seriousness, the elevated and intellectual.

Like Brian McHale (1987:5) when he spoke of "a reaction against the poetics of early-twentieth-century modemism", Harry Levin (1966:271) had already in the 1960s adopted the anti-intellectual stance of postmodernism.

Although postmodernism is more concerned with ontological than with epistemological questions (McHale, 1987:11) the issue is only a matter of emphasis. In reality postmodemism needs, or should not be seen as a distinct period but rather as an adjusted frame of mind. This approach is illustrated amongst others by attempts to characterize eighteenth-century novels as "post- 
modern". In his rereading of Diderot's novel Jacques le fataliste et son maitre André P. Brink (1988) discovers quite a few postmodernist narrative strategies in this presumably antiquated text.

\section{Representation of the past}

The relationship between literature and "reahity" is often reduced to the presumed opposition between original creation (creatio) and mere imitation (mimesis). A radical polarization of these concepts is indeed founded on an erroneous view of the creative process in literature: (re)-creation is not possible without implicitly referring to empirical reality and its coherence and hierarchies.

Similarly, imitation cannot be equated to a mere mirroring of reality, nor can it occur without a degree of "creative" re-creation (selection and combination). In this sense, De Deugd (1975) contends, all literature is mimetic in nature.

What must be taken into account is that all representation is interpretation and that it takes place within a communicative framework that is firmly embedded in time and space. This view implies that the receiver shares a common code (of expectations and conventions) that will be brought into play. Ricoeur (as quoted by Clark, 1990:168), too, resists those views that see mimesis as "derived from" or second-hand; in fact, he emphasizes human intervention in the process of representation. To imitate an action (an event) is totally different from representing physical reality: "(a)ction can itself be seen as a kind of structuring, the acquisition of an identity through inscribing oneself into a role in the world". In Ricoeur's view (see Clark, 1990:168) the referent of a narrative, namely human action, is already an action which has been "symbolized" - it is never "raw or immediate reality".

For this reason, mimesis requires an intimate knowledge of the "semantics of action". On the one hand it must create structures that interpret and organize knowledge; and on the other hand it must effect the reception and assimilation of those structures. In this view, all representation is indeed ideologically coloured. Should one want to go further, the same can be said of all literary discourse because ultimately such discourse displays a specific (systemic and ideological) coherence.

The most typical metaphors of postmodemist narrative are the journey, the labyrinth, the (broken) mirror and the tread in the dark (Fokkema, 1984:50 and Janssens, 1997:19). These metaphors allude to a world that is characterized by fragmentation and relativism; where cohesive master narratives have disappeared and where concepts like "reality" and "the past" have been deconstructed.

Literature can seemingly no longer represent reality because human beings are confined within the opacity of language and the subjectivity of epistemology. All 
that logically remains is that all literature must be seen as reporting to, and presenting the self.

Postmodern artefacts underline their representational aspect by saying, in effect about e.g. a brush stroke, that it is a stroke and not representation. The same stategy takes place in modem literature and historiography (Ankersmit, 1990:176) when rendering the past takes on the guise of ostensibly trivial "micro stories" reportings in which the focus is frequently placed on apparently unimportant figures whose (auto)biographies nevertheless illuminate a significant historical setting. In traditional historiography the reader is invited to view the story as transparent and like the brush strokes of naturalistic painting, the language itself becomes the means by which an illusion of the past is created. In postmodern historiography the micro-story itself possesses a reality.

Ankersmit (1990:168) quotes Danto's remark that "artistic representation is logically tied up with putting reality at a distance". Until "reality" is projected in representation it remains mere unformulated potential. When it, however, has been formulated, made into a concept, it becomes reality, and as such the conceptual framework that defines our selves and our circumstances. Reality only "exists" when we confront it or are contrasted to it. The past is therefore how we represent it and it is the task of the historian to discern a pattern in the welter that constitutes the actions, thoughts or writings of people in the past. This also applies to the author as historian, a role he or she in fact adopts when representing the past (albeit a personal past) retrospectively, as in any autobiographical mode.

\section{Representation of the past in recent Afrlkaans literature}

The representation of the past is most certainly a peculiarity not only of modem Afrikaans literature but is also evident in Dutch hiterature (Ghesquiere, 1996) and in most literatures of people grappling with a traumatic past. Ghesquire's (1996: 230) identification of the Second World War and emigration as two of the most frequent themes in Dutch youth literature is a case in point.

This current interest and preoccupation with history culminates, I believe, in the poles of nostalgia and parody. Nostalgia yearns after an unredeemable past - a nurturing of memories and relics suggestive of a bygone era somehow "better", "more honest", and "finer" (see Van Coller, 1995a:199). Parody, in contrast, is the satirical copying, adapting or re-working of something earlier held in esteem, finding its expression in literature through intertextuality. The post-modem concern with history may seem initially a form of nostalgia, but - in its selfconscious and often overt confrontation with the historical past and with the diachronic canon (both the texts and the received readings) - it is more accurately seen as parody (Hutcheon, 1988:4, 39, 45 and 93). 
In distinguishing between these two ways of describing the past it is evident that there also is an ideological divide: the parodic (postmodernistic) stance is clearly critical of the past and the then existing political situation (especially apartheid and its effects). The nostalgic retrospect, in contrast, often focuses on the Afrikaner's traumatic past and his battle for survival, especially as victim of British imperialism.

Another significant feature of these two stances is the prevalence of the autobiographical mode of writing; that which Foster (1987) describes as "the confessional turn". The autobiographical "pact" implies identity of author, narrator and the main character Lejeune (1975). One could also add focalizer to this equation (Genette, 1990).

Although the I-perspective seems to be the only possible narrative situation in the autobiography proper, Naomi Tamir (1976), Lejeune (1975) and Genette (1990) concur that "third-person autobiography" is possible since there is always a distance between the " $I$ " of the present and the past and the subject of an énonciation is always an "I". As Genette (1990:768) elegantly states: "(f)or what defines narrative identity ... is not legal identity ... but the author's serious adhesion to a story for whose veracity he assumes responsibility". This "adhesion" is usually publicly proclaimed by means of various authenticating signals (cf. Ghesquiere, 1996:229).

With the foregoing in mind, I shall use what remains of this article in an attempt to establish a typology that will serve as model for placing and describing current Afrikaans (prose) texts dealing with the representation of childhood and youth within the parameters of nostalgia and parody.

A typology is a generalizing conceptual framework arrived at through a process of abstraction. Because abstraction presupposes selection, the relation between the typology as construct and the phenomenon it proposes to map out, is one of approximation. The criteria for the construction of a typolgy are exhaustiveness and (mutual) exclusiveness (Van Coller, 1996:268).

In Afrikaans literary studies there have been several attempts to develop a descriptive model of narration. H.M. Viljoen's model (1985) is one such an attempt. Viljoen tries to develop a narrative model based on the well-known Jakobson communication model (see Van Coller \& Van der Berg, 1989, for an extended discussion of this model). Viljoen discriminates between a writer's code and a reader's code (author's/reader's; sender's/receiver's) and asserts that the codes are structured from the familiar triad: syntax, semantics, and pragmatics.

Despite Viljoen's strenuous effort to establish a reasoned and scientific foundation for his model, it remains in the final analysis a somewhat arbitrary 
assemblage of diverse categories. He himself admits that the model is not uniformly logical (Viljoen, 1985:43); and he acknowledges in conclusion that the ultimate appeal it holds for him is personal: he has already found it "useful in teaching" (Viljoen, 1985:43). Yet Viljoen should not be taken to task that he fails to offer scientific credibility to his model, or that he introduces vague distinctions like those between "search light" theories and "observation" theories. Typologies (and models) are abstractions that never can correspond exactly to what they strive to classify. Nevertheless they offer indispensable heuristic aid that is invaluable (Mouton \& Marais, 1989:138).

W. Drop (1970) offered practical guidance in the analysis of narrative texts, yet still firmly in the structuralist paradigm. Though hie was not primarily concemed with a typology or a model, it is notable that many of the narrative categories that he identified figured in the latter (and more informative) approaches of Viljoen (1985) and Van der Berg (1993). Already it is apparent that a number of categories were likely to recur and prove themselves relevant. Especially Van der Berg developed earlier models through emphasizing the (role of the) receiver within the process of literary communication (Van der Berg, 1993:77). He especially stressed the "skills" or capabilities the receiver must possess to decode the message competently. In effect this suggestion was a re-statement of what Viljoen had earlier labelled the "receiver's code" (Viljoen, 1985:39).

The typological grid that follows shortly is fashioned largely from the models mentioned, and also from my own research and teaching over nearly three decades. The model is by no means exhaustive, yet it is intended to offer a practical model that will aid the description and classification of contemporary (prose) works. Because my intention is the broad classification of books, I shall disregard the commonly recognized structuralist categories (space, time, etc.) but it is certain that these categories could be useful in refining and elaborating my model. The proposed model would assist the arranging of a large corpus of work into recognized genre and narrative categories; and would have the additional benefit of registering salient aspects of the present literary system.

The first two categories, genre and sub-genre are self-explanatory. My intention is to show that my further remarks are not limited to canonized genres, but that they also apply to marginalized genres, such as youth literature. I have included one poetry text to illustrate the versatility of the model. The recent appearance of drama texts with a historical aspect - those for example, by André P. Brink and Reza de Wet - would further test the range of the model's usefulness. 


\begin{tabular}{|c|c|c|c|c|c|c|c|c|}
\hline 童㥼 & + & + & + & $\stackrel{+}{+}$ & $H$ & & . & . \\
\hline ๘ٌ & + & + & + & + & 0 & 0 & + & + \\
\hline 量 & + & + & $\stackrel{+}{+}$ & + & . & $H$ & + & H \\
\hline 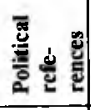 & + & $\stackrel{9}{+}$ & $\begin{array}{l}0 \\
+ \\
\end{array}$ & $\stackrel{+}{+}$ & $H$ & $\therefore$ &. & . \\
\hline ڤ̆ & $\stackrel{\circ}{+}$ & + & + & 우+ & $H$ & $H$ & $H$ & $H$ \\
\hline 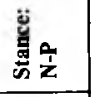 & $\hat{i}$ & $\begin{array}{l}\infty \\
z\end{array}$ & $\stackrel{\infty}{\stackrel{1}{z}}$ & $\frac{n}{z}$ & 是 & $\stackrel{s}{\mathbf{z}}$ & $\frac{n}{2}$ & $\frac{s}{z}$ \\
\hline 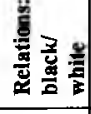 & o & 吕 & 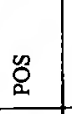 & $\stackrel{+}{+}$ & $\begin{array}{l}\circ \\
+ \\
\end{array}$ & H & . & $H$ \\
\hline 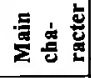 & $\sum$ & $\sum$ & 岁 & 5 & $\sum$ & $\sum$ & 㽞 & 亩 \\
\hline ँㅗ & 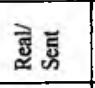 & 居咅 & 产 & 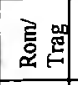 & $\bar{\Xi}$ & $\bar{\Xi}$ & 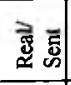 & \begin{tabular}{|l} 
吅 \\
Е
\end{tabular} \\
\hline 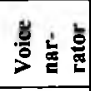 & 5 & 5 & 5 & $\Xi$ & $\stackrel{3}{3}$ & 愛尌 & 可 & 臣蒠 \\
\hline 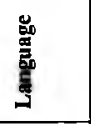 & 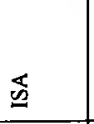 & $\sum_{\substack{\infty \\
\infty}}^{\mathbb{\infty}}$ & 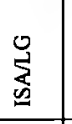 & ఏ્త్ & \begin{tabular}{l}
0 \\
\multirow{2}{*}{} \\
0 \\
0
\end{tabular} & 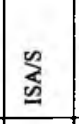 & 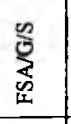 & 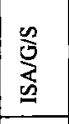 \\
\hline 窝 & 管 & 孚 & 孚 & 蛋 & 爱 & 罢 & 畧 & 思 \\
\hline 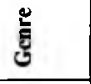 & 涪 & $\stackrel{0}{2}$ & 㲅 & $z$ & $\underline{z}$ & $z$ & $z$ & $z$ \\
\hline & 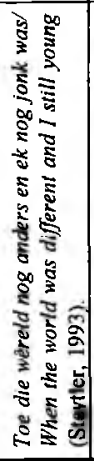 & 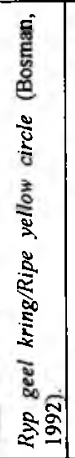 & 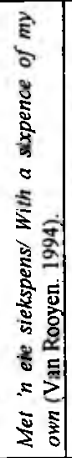 & 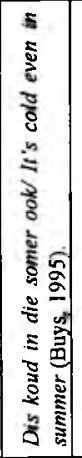 & 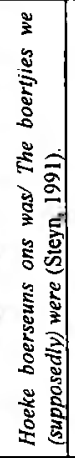 & 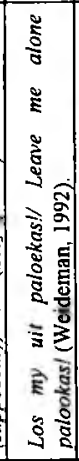 & 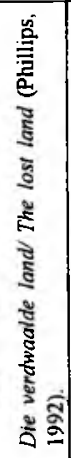 & 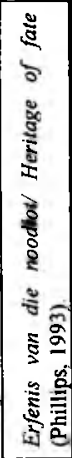 \\
\hline
\end{tabular}




\begin{tabular}{|c|c|c|c|c|c|c|c|c|}
\hline$\frac{d}{g}$ & & : & : & & . & : & : & \\
\hline 安高 & + & . & + & 0 & - & . & . & \\
\hline 畜 & + & H & + & + & . & . & $:$ & : \\
\hline 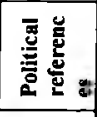 & & . & $:$ & . & i. & $:$ & $:$ & : \\
\hline$\stackrel{8}{8}$ & + & $:$ & $:$ & 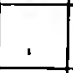 &. & $:$ & $:$ & : \\
\hline 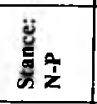 & & 高 & zzz & $\stackrel{2}{2}$ & $\underline{a}$ & $\Sigma$ & $E$ & $\stackrel{\infty}{\stackrel{2}{2}}$ \\
\hline 毫 & & + & H & . & H & H & . & H \\
\hline 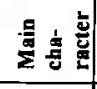 & 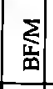 & $\sum$ & 笛 & $\underline{z}$ & 步 & $\xi$ & $\xi$ & $\xi$ \\
\hline$\frac{0}{2}$ & $\mathrm{~g}$ & 勇总 & $\overline{\underline{\mathbb{J}}}$ & 疍㤐 & बूँ & 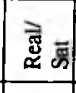 & 总 & 要 \\
\hline 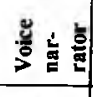 & & 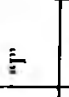 & 5 & 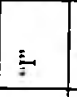 & 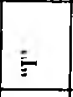 & $E$ & 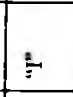 & 1 \\
\hline 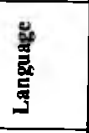 & 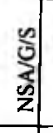 & 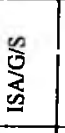 & $\begin{array}{ll}x \\
0 \\
0\end{array}$ & 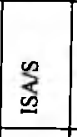 & \begin{tabular}{|l} 
\\
0 \\
0 \\
on \\
\end{tabular} & 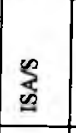 & 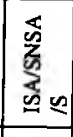 & 染 \\
\hline 言言 & & 思 & $\stackrel{\mathbb{x}}{\Sigma}$ & 娄 & 要 & $\frac{2}{2}$ & \begin{tabular}{|l|l|} 
\\
\end{tabular} & $z$ \\
\hline قِّ & z) & $\mathrm{z}$ & $z$ & $z$ & $z$ & $z$ & $z$ & $z$ \\
\hline & | & 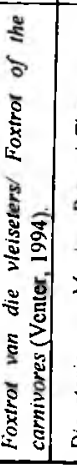 & 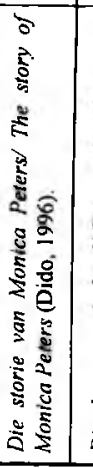 & 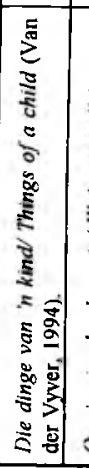 & 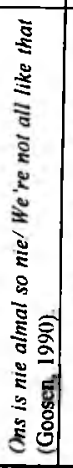 & 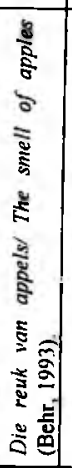 & 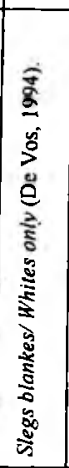 & 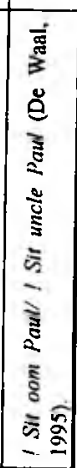 \\
\hline
\end{tabular}


Susan Lanser (1981:166) asserts that the Western European tradition expects that a narrator be white, male, upper middle class, and heterosexual. In addition diction must be "standard". For this reason I have included the classifications of language, voice/narrator, race and main character. From the scheme it will be immediately apparent that, contrary to expectations, informal and substandard language feature in both nostalgic and parodic texts - often with different effects. Wicks $(1974: 240)$ provides a useful schemata to plot the way in which a writer renders reality. A realistic, so-called objective presentation would be considered nil, with reality being placed on a negative or a positive scale. A romanticized portrayal would be registered positive and a satirical portrayal negative. According to the schemata it is clear that works of both Steytler and Phillips could be classified as realistic and sentimental, though they differ ideologically.

In the South African context the most important markers of ideological stance are to be detected in race relations (especially between white and black), the expression of political attitudes, sex and religion. For this reason I have taken these categories as typological markers. The endings of literary works are usually seen as discursively "privileged" and important signs of the authorial stance. In recent years the endings of novels were furthermore the focus of attention during quite a few literary congresses in South Africa. I have therefore included this category "the nature of ends" in the grid.

The sexual and ideological situation presented in a literary work are registered nil (" 0 ") if sex or ideological content appears neutral or is not existent. A discernible stance is marked on a scale from 0 to $10, \mathrm{~N}$ plus an integer if the attitude is nostalgic, and $\mathrm{P}$ plus an integer if the attitude is parodic. $\mathrm{P} / \mathrm{N}$ or $\mathrm{N} / \mathrm{P}$ indicates an engagement of the parodic and nostalgic stances with the domineering one being the first-mentioned. $\mathrm{P}(+\mathrm{N})$ depicts a parodic stance with nostalgic digressions.

In the following "typological grid" an overview of recent Afrikaans literary works is provided. The list consists of sixteen books all of which have been published in the last seven years. With the exception of one volume of poetry, all the books belong to different prose genres. I have tried to translate the Afrikaans titles into English but must concede that it is almost impossible, in many instances, to translate the various nuances and connotations.

It is impossible to deal extensively with all the chosen books. Suffice to say that these books constitute a representative sample from a much larger corpus. My criteria for selection were chiefly the positive reception of a text, a strong autobiographical quality - which nearly all the works share (a characteristic of current Afrikaans prose), and the fact that a work represents an important narrative sub-genre. It was important to differentiate between the various types of autobiography, as they can be graded in a spectrum from non-fiction to fiction. 
The narrative contract between narrator and reader can vary enormously depending on whether the autobiography is a serious portrayal (as Jaap Steyn's book) on the one hand or a disguised or pretended (spurious) "autobiography" on the other. Each particular type will need a different reading strategy and critical response.

I have further tried to include "classics" like Goosen's novella Ons is nie almal so nie with a young girl as focalizer - comparable to the narrative situation in What Maisie Knew by Henry James. In a sense the novels by Behr, De Vos and Van der Vyver are permutations of this basic structure that presents a critical, youthful view of some traumatic period, either in personal life or in a more general history.

The two novels by Abraham Phillips are noteworthy, not only because they have been written by a "coloured" - a not too frequent event in Afrikaans - but because Die verdwaalde land was published with an introduction by André $\mathrm{P}$. Brink, the well-known South African author and critic. This accompanying introduction can be seen as a form of explicit "mediating" canonization that renders the book acceptable to a group of largely white readers - a circumstance of special significance in view of the negative reception of Phillips's next two books (cf. Hattingh, 1997). A few years later such a mediating strategy, with reference to the books by Scholtz and Dido, was no longer necessary.

Two of the two most vehement reactions to existing ideology, the novels by Venter and De Waal, are interesting from a genre point of view. Venter's novel is cast in the familiar mould of a "farm novel", but is actually a persiflage of almost all the central characteristics of this extremely important subgenre in Afrikaans writing. De Waal's novel ostensibly typifies the "youth novel", but in fact it is like the Venter novel - a strong revolt against the "Father" and a whole network of patriarchal values and beliefs.

\section{Key to abbreviations}

\begin{tabular}{|c|c|c|}
\hline $\begin{array}{l}\text { Genre: } \\
\text { SS = short story } \\
\text { PO = poetry } \\
\text { NS = novelistic sketches } \\
\mathbf{N}=\text { novel } \\
\text { YN = youth novel }\end{array}$ & $\begin{array}{l}\text { Subgenre: } \\
\text { ABN = autobiographical sketches } \\
\text { AB = autobiography } \\
\text { ABN = autobiographical novel } \\
\text { DAB = disguised autobiography } \\
\text { PAB = pretended autobiography } \\
\mathbf{N} \quad \text { = novel }\end{array}$ & 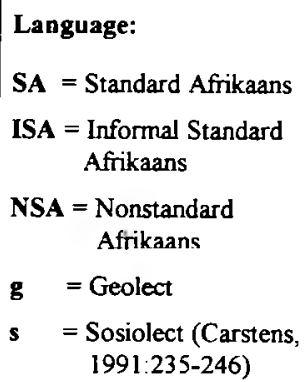 \\
\hline
\end{tabular}




\begin{tabular}{|l|l|}
\hline Main character & Mode \\
$\mathbf{W M}=$ White male & Real = realistic \\
$\mathbf{W F}=$ White female & Sent = sentimental \\
$\mathbf{B M}=$ Black male & Rom = romantic \\
$\mathbf{B F}=$ Black female & Trag = tragic \\
& Sat = satirical \\
& Com = comical \\
\hline
\end{tabular}

Foxtrot van die vleiseters can be used as an example. It is written in the vein of the farm novel, and can be described as a disguised autobiography when the personal circumstances of the author (who grew up on a farm in Burgersdorp and later emigrated to Australia to open a vegetarian restaurant) are taken into account. This novel is written in informal standard Afrikaans, often incorporating linguistic features from sociolects and geolects (e.g. suburban Afrikaans). The narration (focalisation) is in the I-perspective, situated in the present time and the narrative mode is both satirical and comical. The main character is a white young male person and the relations between white and black people are described both in positive and negative terms. Although nostalgia is not totally absent, the parodic stance is prevalent. From the grid it would appear that, as far as the depiction of sex, ideology, politics and religion are concerned, Foxtrot van die vleiseters is near the negative pole. Graphic descriptions of sexual relations across the colour bar, vehement attacks on typical apartheid ideology and politics and an implicit questioning of traditional Christian religion, as practised in South Africa, substantiate this reading.

From this typological grid it becomes clear that I have graded the books according to the two opposing poles: nostalgia and parody. If one takes reviews into account, the books in the grid can be graded not only according to an ideological stance, but also with reference to stylistic features. Roughly all the books that are predominantly "negative" have been depicted as experimental or "postmodern" by reviewers and those that are either ideologically neutral or closer to the nostalgic ("positive" pole) can be termed traditional in terms of stylistic features.

This seems to indicate that the parodic, satirical stance displays the stylistic features common to postmodern texts. Semantic characteristics include an antipathy toward traditional religious, political and moral values, accentuated by linguistic features, namely a deviation from standard Afrikaans. Pragmatically these texts deviate from canonically entrenched expectations pertaining to language, form, subject matter, etc. and therefore implicitly (and explicitly) make a strong appeal to their readers to change their stereotyped perspectives. 
Representation of the past is only worthwhile when it benefits the present and the future. To recapture the past in the form of stories is to (re)structure it, relive it and to give it meaning: "the very discourse of representation as expression is symptomatic of the desire for a language that will make the writer the master of his meanings" (Foster, 1987:2). In the South Africa of today the past is scrutinized by all and sundry and a Truth and Reconciliation Committee is presently conducting hearings. The coming to grips with a traumatical past and the wliole difficult process of confession and forgiving has already taken place in contemporary Afrikaans writing (cf. Van Coller, 1997).

\section{Bibliography}

Ankersmit, F R 1990. De navel van de geschiedenis. Over representatie en historische realiteit. Groningen : Historische Uitgeverij

Behr, Mark 1993. Die reuk van appels Kaapstad: Queillerie

Bosman, P.J. 1992. Ryp geel kring. Pretoria : HAUM-Literêr.

Brink, André P. 1988. Die postmoderne roman: 'n skakel met die 18e eeu? Tydskrif vir Literatuunwetenskap, 4(4):378-393, Desember

Buys, Sheugnet. 1995. Dis koud in die somer ook Pretoria : Van der Walt.

Carstens, W.A.M. 1991. Norme vir Afrikaans. Enkele riglyne by die gebruik van Afrikaans. Pretoria : Academica.

Clark, S.H. 1990. Paul Ricoeur. London : Routledge

Crane, R S. 1975. In: Beaurline, Lester A. (ed.) 1975. A mirror for modern scholars Indianapolis : Bobbs-Merril

De Deugd, C. 1975. Het mimetisch karakter van de literatuur. Niezw Ilaams Tijdschrift, 28(8) 711-734, October.

De Vos, Pierre. 1994. Slegs blankes Whites only. Pretoria : Kagiso Literêr.

De Waal, Johann 1995. I Sit oom Paul Kaapstad : Human en Rousseau.

Dido, E.K.M. 1996. Die storie van Monica Peters. Kaapstad : Kwëla-boeke.

Drop, W. 1970. Indringend lezen 2. Analyse van verhalend prosa Groningen : WoltersNoordhoff.

Fokkema, D.W 1984. Literary history, modernism and postmodernism. Amsterdam/ Philadelphia : John Benjamins

Fokkema, D.W \& Ibsch, Elrud. 1987. Modernist conjectures. A mainstream in European literature 1910-1940. London : Hurst.

Foster, Dennis A. 1987. Confession and complicity in narrative Cambridge : Cambridge University Press.

Genette, Gérard 1990. Fictional narrative, factual narrative Poetics Todoy, 2:4:755-773, Winter.

Ghesquiere, Rita. 1996. Omkijken naar wat 'voorgoed' voorbij is. Het autobiograpish schrijven in jeugdliteranuur. Volkskunde, 96(3):220-262.

Goosen, Jeanne 1990 . Ons is nie almal so nie. Pretoria : HAUM-Literêr

Hattingh, Marion 1997. Abraham Phillips en die Afrikaanse literêre kritiek. In: Willemse, H, Hattingh, M., Van Wyk, S \& Conradie, P. 1997. Die reis na Paternoster. 'n Verslag van die tweede swart Afrikaanse skrywersimposium gehou op Paternoster vanaf 29 September tot I Oktober 1995. Bellville : Universiteit van Wes-Kaapland p. 94-105

Hutcheon, Linda. 1988. Metafiction: A poetics of postmodernism. London/New York Routledge

Janssens, Marcel. 1997. Canon en cultuur in crisis? Reflecties over onze consumermaatschappij D F. Malherbe-gedenklesing 16. Acta Varia Bloemfontein : UVS. 
Lanser, S. S. 1981. The narrative act. Point of view in prose fiction. London : Routledge \& Kegan Paul.

Lejeune, Phillipe 1975. Le pacte autobiografique. In: Le pacte autobiografique. Parys : Lettres Modernes

Levin, Harry 1966. What was Modernism? In Levin, Harry. Refractions: essays in comparative literature. New York : Oxford University Press. p. 271-295.

Lotman, Jurij. 1973. Die Struktur des künstlerischen Textes. Rainer Grübel Hrsg. Frankfurt : Suhrkamp.

McHale, Brian. 1987. Postmodernist fiction. New York : Methuen

Mouton, J. \& Marais, H.C. 1989. Metodologie van die geesteswetenskappe. Basiese begrippe Pretoria : Raad vir Geesteswetenskappe

Phillips, Abraham. 1992. Die verdwaalde land. Kaapstad : Queillerie

Phillips, Abraham. 1993. Erfenis van die noodlot Kaapstad : Queillerie.

Scholtz, A.H.M. 1995. Vatmaar Kaapstad : Kwêla-boeke

Steyn, J.C. 1991 Hoeke boerseuns ons was. Kaapstad : Tafelberg.

Steytler, Klaas. 1993. Toe die wêreld nog anders en ek nog jonk was. Kaapstad : Queillerie

Tamir, Naomi. 1976. Personal narrative and its linguistic foundations. PTL: A Journal for Descriptive Poetics and Theory of Literature, 1(3):403-429.

Todorov, T. (ed). 1982. French literary theory today. Cambridge : Cambridge University Press

Van Coller, H.P. \& Van der Berg, D.Z.J. 1989. Keursteen. 'n Literatuurhandboek. Pietermaritzburg : Shuter en Shooter p. 189-195.

Van Coller, H.P. 1993. "Swaardra al aan die een kant: swaarwigtigheid in die Afrikaanse prosa". Stilet, 5(2):129-141.

Van Coller, HP. 1995. Tussen nostalgie en parodie: die Afrikaanse prosa in die jare negentig (deel 1). Tydskrif vir Geesteswetenskappe, 35(3): 197-208, September

Van Coller, HP. 1995. Tussen nostalgie en parodie: die Afrikaanse prosa in die jare negentig (deel 2). Tydskrif vir Geesteswetenskappe, 35(4):271-279, Desember.

Van Coller, H P 1996. Yardstick or straight jacket? Notes on the process of canonization In: Hendrix, H., Kloek, J., Levie, S., Van Peer, W 1996. The search for a new alphabet. Literary studies in a changing world In honor of Douwe Fokkema Ansterdam/ Philadelphia : John Benjamins. p. 267-271.

Van Coller, H.P. 1997. Die waarheidskommissie in die Afrikaanse letterkunde. Stilet, (2):9-21, September

Van der Berg, D.Z.J. 1993. Elsa Joubert. 'n Kommunikatiewe benadering. Pietermaritzburg University of Natal. (Ph.D. thesis.)

Van der Vyver, Marita. 1994 Die dinge van ' $n$ kind. Kaapstad : Tafelberg

Van Rooyen, Engela. 1994. Met 'n eie siekspens. Kaapstad : Tafelberg.

Venter, Eben. 1994. Foxtrot van die vleiseters. Kaapstad: Tafelberg

Viljoen, Hein. 1985. Die Suid-Afrikaanse romansisteem anno 1981. 'n Vergelykende studie Potchefstroom : PU for CHE. (D.Litt-thesis.)

Weideman, George 1992. Los my uit paloekas! Kaapstad : Tafelberg.

Wellek, René \& Warren, Austin. 1976. Theory of literature. Middlesex : Penguin Books

White, Hayden. 1973. Metahistory: The historical imagination in nineteenth-century. Europe Baltimore and London: The Johns Hopkins University Press.

Wicks, Ulrich. 1974. The nature of picaresque narrative: A modal approach. P.M.L.A., 89: 240-249. 